\title{
A materialidade do libro na creación de espazos figurados en El gran hotel Wes Anderson, de Nuria Díaz
}

\author{
IE-CIEC-Universidade do Minho/ LITER21-Universidade de Santiago de Compostela \\ http://orcid.org/0000-0002-5102-5078
}

[Recibido, 2 maio 2021; aceptado, 31 maio 2021]

[G-Pedreira, R. (2021). A materialidade do libro na creación de espazos figurados en El gran hotel Wes Anderson, de Nuria Díaz. Boletín Galego de Literatura, 58, "Notas", 29-42] DOI http://dx.doi.org/10.15304/bgl.58.7683

RESUMO El gran hotel Wes Anderson (2018) é un libro-informativo da autoría da ilustradora galega Nuria Díaz que experimenta coa materialidade a partir da creación de espazos figurados que xogan co rol do lector como hóspede dun hotel, cuxas estancias pode ir recorrendo páxina a páxina. A través delas coñecerá a vida e obra do cineasta Wes Anderson, así como os trazos máis característicos do seu labor profesional, mediante informacións explicadas con claridade e moi coidadas a nivel estético, dándolle especial protagonismo ao compoñente visual. O obxectivo deste traballo é analizar a maneira na que toma forma a proposta a través da análise textual e compositiva do libro, prestándolle especial atención á súa natureza en canto libro-obxecto e á función dos paratextos, para rematar reflexionando sobre como a súa forma e contido o achegan ou distancian do público infantil, xuvenil ou adulto.

PalAVRAS CHAVE: Libro-obxecto; materialidade; paratextualidade; Wes Anderson; Nuria Díaz.

ABSTRACT El gran hotel Wes Anderson (2018) is an informative book by the Galician illustrator Nuria Díaz that experiments with materiality through the creation of figurative spaces that play with the reader's role as a hotel guest, whose rooms can be visited page by page. Through them, the reader will learn about the life and work of the filmmaker Wes Anderson, as well as the most characteristic aspects of his professional work, by means of clear and aesthetically very careful information, giving special prominence to the visual component. The aim of this work is to analyse the way in which the proposal takes shape through the textual and compositional analysis of the book, paying special attention to its nature as a book-object and to the function of the paratexts, to conclude by reflecting on how its form and content bring it closer to or distance it from adults or young audiences. KEYWORDS: Book-object; materiality; paratextuality; Wes Anderson; Nuria Díaz.

\section{Introdución}

No ano 2014, en Valladolid celebrouse un festival de ilustración chamado Ilustratour, con charlas, talleres e entrevistas con distintos editores. Nel 
participou a artista galega Nuria Díaz, a onde acudiu co seu portfolio logo de poucos anos dedicándose profesionalmente á ilustración, onde recollera, entre outras, unha ilustración fanart ${ }^{1}$ de Sam e Suzy, protagonistas da película Moonrise Kingdom, do cineasta Wes Anderson. Nun dos contactos que mantivo coñeceu a un editor da editorial Lunwerg, que anos despois volveu contactar con Díaz para propoñerlle o proxecto dun libro sobre a figura de Anderson, ao cal a artista non se puido resistir. Deste xeito, no 2018 saía do prelo El Gran Hotel Wes Anderson, a creativa obra informativa de elevado coidado estético sobre a que xira este traballo².

Un dos maiores puntos de interese, que determinou a escolla, é que nesta obra a construción do discurso asenta na materialidade do libro en canto artefacto, situándonos no amplo universo do libro-obxecto. Nos últimos anos, a investigación sobre o libro-obxecto, especialmente no referido á produción de obras infantís, está en constante evolución e proba disto son os diversos monográficos que foron construíndo un itinerario de aproximación e especialización na temática dende distintas áreas como a pedagoxía, a psicoloxía infantil, as artes plásticas, a literatura ou o deseño (Ramos 2017; Tabernero, 2019; Mociño, 2019; Reis da Silva, 2020; e Sousa Pereira, 2020).

O libro-obxecto é definido por Silva (2020, p. 8) como "artefacto ou um objeto híbrido no qual se conjugam intersemioticamente registos estéticos diversos como o discurso literário, a ilustração, o design ou a engenharia do papel” que, pese á gran potencialidade que ofrece para a creación actual de obras especialmente atractivas para o público máis novo, non está destinado en exclusiva á infancia (Ramos, 2017). Nestas propostas, a introdución de distintas estratexias mecánicas converten o lector nun receptor activo, cuxa intervención manipulativa é esencial para acceder á mensaxe, dando lugar a un lector colaborador dende o punto de vista físico e a un tipo de lectura interactiva (Tabernero-Sala, 2017).

1 O termo fanart fai referencia á arte creada polos fans de películas, personaxes, videoxogos e obras literarias co obxectivo de homenaxear as obras da súa preferencia, a través de propósitos lúdicos e expresivos, e, na súa orixe, non lucrativos (Lugo Rodríguez, 2010).

2 Esta información, así como outras recollidas ao longo do texto sobre a opinión e experiencia da ilustradora na creación e difusión do libro, proveñen directamente de Díaz a través dunha breve entrevista ad hoc, cuxas preguntas e respostas foron trasladadas aos distintos axentes comunicativos a través do correo electrónico. 
A importancia da materialidade de El gran hotel Wes Anderson reside na consideración do libro como un espazo de representación figurado que se constrúe a partir da interpretación que a súa autora fixo da filmografía do cineasta. Deste xeito, as distintas estancias/capítulos deste particular hotel/ libro van guiando o lector por un percorrido físico de carácter formativo/informativo que profunda na figura do director a nivel persoal-biográfico, pero tamén profesional. Dentro da filmografía de Anderson, The Grand Budapest Hotel supuxo un momento de inflexión no recoñecemento do creador debido ao éxito acadado entre o público xeral e a crítica especializada. O filme, mediante a simbiose da comicidade e do patetismo inherente dos personaxes andersonianos, centrados en aparentar, pero auténticos na súa excentricidade, sitúa o espectador nas inmediacións do gran hotel que dá título á produción, o cal intenta recuperar a grandeza que ostentaba no pasado. Este impoñente lugar trasládase agora ás páxinas impresas a través do estilo característico de Díaz, para funcionar como elemento de cohesión narrativa das informacións contidas na obra. A nivel de formato, comparte moitos dos elementos característicos dos dollhouse books analizados por Silva no artigo "Livros que são casas ou quando ler também é brincar" (2020), que xogan coa simulación da fisicidade das casas de bonecas. A investigadora explica que se trata de obras que "testemunham e configuram, em certa medida, um bem, concomitantemente material, na medida em que mimetizam um bem imóvel que é uma casa, e imaterial, porque são livros, são cultura" (Silva, 2020, p. 181).

Debido ao seu carácter biográfico, a obra de Díaz pertence ao ámbito dos libros informativos, tamén coñecidos como libros de coñecementos, de divulgación, documentais ou de non ficción. Trátase de propostas vinculadas ao uso do discurso informativo, estruturado e veraz que estimulan a curiosidade e o interese do lector (Sampériz, Tabernero, Colón e Manrique, 2021), que ofrecen distintos tipos de lectura entre as que o receptor debe decidir, dándolle prioridade á conexión co contido -lectura eferente- ou coa emoción -lectura estética- (Rosenblatt, 2002; Carter, 2001; Garralón, 2013). Por outra parte, a vinculación significativa entre arte e coñecemento das novas propostas editoriais do libro informativo foron reforzadas pola utilización de compoñentes lúdicos e físicos que as aproximaron ao mundo do libroobxecto, e aumentaron a presenza de elementos de ficción co propósito de favorecer a posibilidade de realizar unha lectura estética e chamar a atención dos máis novos. Nun artigo recente sobre as estratexias narrativas e pictóricas utilizadas polas biografías para nenos escrito por Marcela Mangarelli (2020, 
p. 44), a autora afirma que "al utilizar una estructura narrativa, las biografías crean un puente entre los dos tipos de lectura estética-eferente”.

A partir destas consideracións previas, o obxectivo desta achega é analizar a maneira na que toma forma a proposta a través da análise textual e compositiva do libro, prestándolle especial atención á súa natureza en canto libroobxecto e á función dos elementos peritextuais, para poder reflexionar, na discusión final, sobre a diversidade de posibilidades que promove no relativo á figura do lector empírico e do lector implícito³.

\section{Pasen e vexan: a materialidade de $E l$ gran botel Wes Anderson}

A obra de Díaz destaca pola importancia e coidado dos peritextos, de xeito que se volven imprescindibles na construción da obra. Sen eles sería imposible entender a maneira na que se artella o contido textual e visual do miolo do libro, xa que sobre eles asenta a creación dos espazos figurados que fan referencia ás estancias do hotel.

Nunha das primeiras preguntas da entrevista a Díaz fíxose referencia ao protagonismo da materialidade do libro como percorrido físico e metáfora da filmografía de Anderson, até incluso incluír un diorama final que o lector pode construír para conseguir unha pequena maqueta do edificio. A autora afirmou ter claro dende o primeiro momento que tiña que tratarse dun libroobxecto; ademais, tamén indica que inicialmente tiña pensando que fose un libro entelado, pero que a idea evolucionou para outro lado logo da creación da cuberta, que xoga co concepto de hotel e do lector-hóspede. En canto ao diorama, responde que tamén foi algo premeditado, xa que quería que houbese algún elemento que puidese saír do propio libro. Por último, na resposta a esta cuestión resalta o seu interese polos libros-obxecto sempre e cando respondan a unha planificación pensada e coidada e que non resulten confusos ou caóticos en aspectos como o formato, aínda que destaca que se trata de produtos moito máis caros de producir e de encaixar no mercado.

3 No Dicionario de Termos Literarios (DiTerLi) do Equipo Glifo (http://bernal.cirp.gal/ords/ $f ? p=106: 50: \ldots .: .:)$ defínese o lector empírico como a persoa real que le efectivamente o texto, e o lector implícito como aquel creado pola propia obra, é dicir, un lector que interpreta e comparte os códigos presentes na mesma. 
Volvendo ao estudo concreto de El gran hotel Wes Anderson, a vista exterior do libro tamén nos adianta a importancia que vai ter a materialidade e guía as hipóteses interpretativas sobre o contido textual e visual da obra. A cuberta mostra a fachada do hotel cun recorte que corresponde ao espazo destinado á porta principal, e compleméntase coa imaxe recollida na contracuberta, que acolle outra recreación do lateral do hotel, onde xa podemos ver a algún dos seus hóspedes, personaxes das películas de Anderson (Figura 1). Ademais, as gardas interiores continúan a intención manifesta da proposta exterior, xa que nas iniciais vemos a Anderson baixo o cartel da recepción, con cámara en man, cuxa imaxe está encadrada de xeito que se pode ver a través do recorte da cuberta; por outra parte, nas gardas finais vemos de novo os hóspedes desfilando coas súas equipaxes escaleiras abaixo, dispostos a abandonar o edificio (Figuras 2, 3).

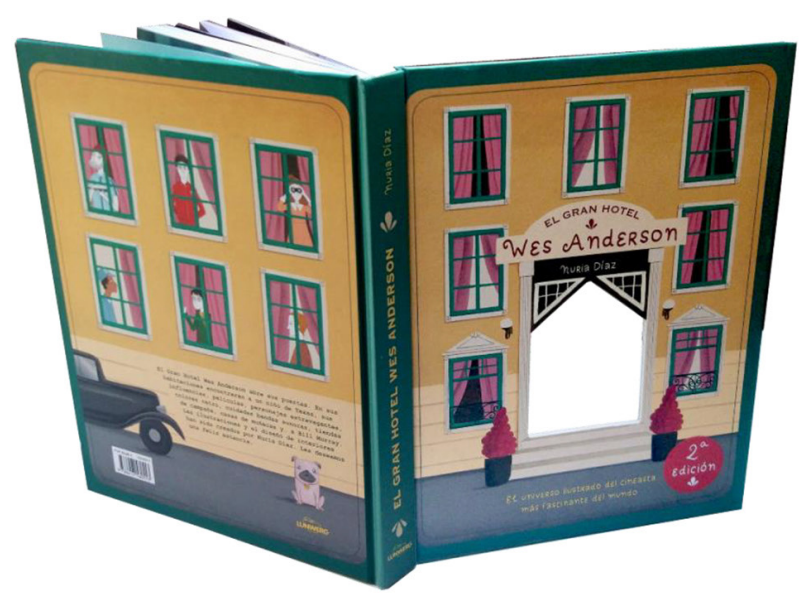

Figura 1. Cuberta e contracuberta do libro.
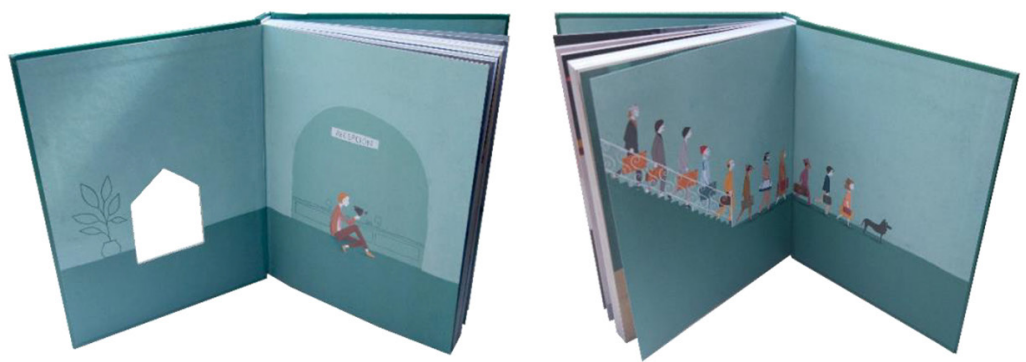

Figuras 2 e 3. Gardas iniciais e finais do libro. 
A primeira páxina coa que nos atopamos logo das gardas iniciais mostra unha vista exterior do hotel, encadrada dentro dun pano simulando o escenario teatral, e presenta o edificio, os seus espazos e hóspedes, como se dunha inauguración se tratara, até rematar coa seguinte liña: "El Gran Hotel Wes Anderson abre sus puertas" (Díaz, 2019, p. 1). De novo é posible observar como toda a composición da obra está coidada até no máis mínimo detalle, xa que esta maneira de presentar a imaxe encadrada cun pano volve a conectarse coa maneira de facer cine do director que, segundo as palabras de Díaz (2019, p. 163), funciona como "una idealización de la realidad que es manipulada a su antojo, para que pueda encajar en el puzle que ha creado en su cabeza".

A continuación, a folla de créditos e a portada interior corresponderían graficamente a un plano picado do mostrador da recepción, e os elementos textuais vense perfectamente integrados na imaxe; de feito, no caso da portada interior, forman parte dun dossier de presentación colocado enriba do moble, de igual xeito que o están o teléfono, o timbre e a chave dunha habitación (Figura 4). Ademais, este último elemento recupérase poucas follas máis tarde, agora na man do propio Anderson, que acode a dar a benvida ao lector como primeiro anfitrión (Figura 5), e que se completa cunha carta de presentación da propia Díaz onde fala da súa relación coas obras do cineasta e como foi evolucionando até recoñecerse como unha verdadeira "andersoniana", apelativo que fai referencia ao fenómeno fandom do director.

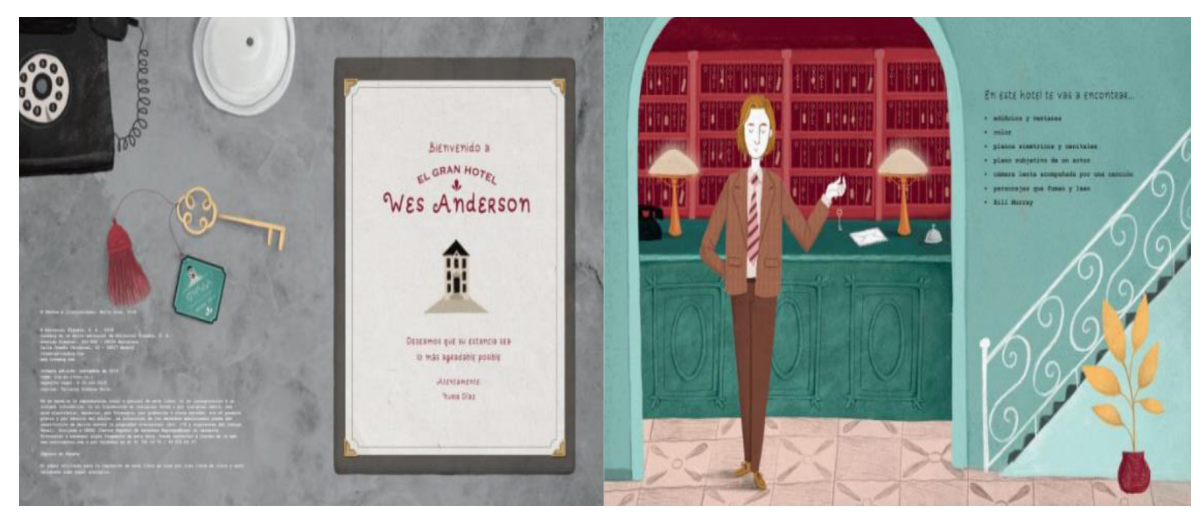

Figuras 4 e 5. Dobre páxina de recibimiento do libro-hotel.

Por outra parte, nestas páxinas presentadas, así como na última de despedida antes das gardas finais (Figura 6), podemos ver as estratexias discursivo-textuais, que se complementan coas gráficas, e que asentan a noción 
do lector como hóspede, tales como a utilización da segunda persoa en distintos fragmentos: "Deseamos que su estancia sea lo más agradable posible" (p. 3), "En este hotel te vas a encontrar" (p. 7), "Si tú también eres andersoniano, ¡bienvenido! [...] Si te estás iniciando en el mundo de Anderson, enhorabuena", "Espero que disfrutes tanto de este libro como yo he disfrutado escribiéndolo" (p. 9).

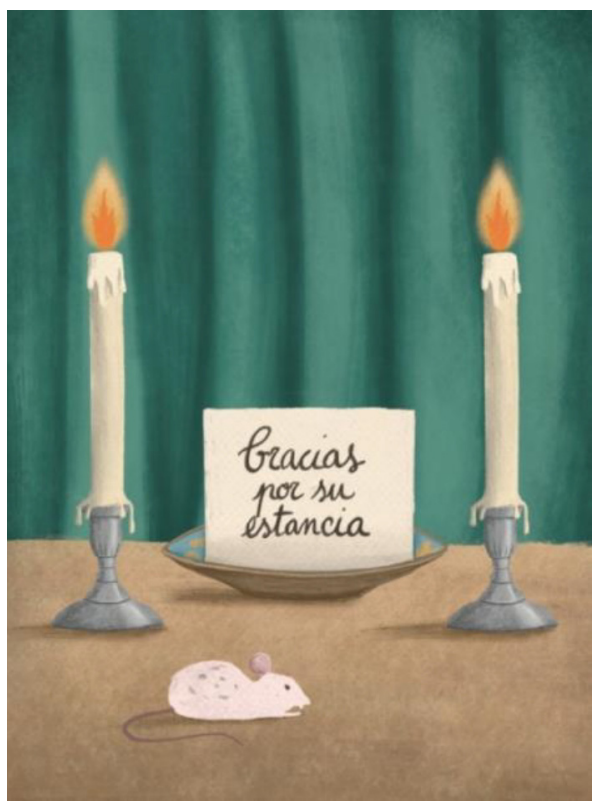

Figura 6. Páxina de despedida do libro-hotel.

Ademais, o paratexto correspondente á dedicatoria móvese ao final da obra de xeito deliberado, xa que Díaz agradece, ademais de á familia, amigos e editores, ao propio lectorado, facendo referencia á experiencia de lectura como un evento sucedido con anterioridade: "Y a ti, como lector/a de este libro: espero que tu viaje por el mundo fantástico de Wes Anderson haya sido precioso" (Díaz, 2019, p. 197).

Neste sentido, noutra das preguntas realizadas na entrevista a Nuria Díaz preguntábaselle polo tipo de lectorado que se imaxinaba mentres estaba facendo o libro. A artista respondeu que entende que o cine de Anderson é complexo e pode non gustar a todas as persoas, polo que non pensaba tanto en idades como na xente que vía unha película de Anderson e non lle convencía, xa que considera que coñecer un pouco os contextos e as historias que hai detrás de cada película axuda a poñer en perspectiva as producións e 
pode facer que o público non conforme lle volva dar unha oportunidade. Así, entende o libro "como unha guía para os que non o coñecen e como unha especie de libro tributo para os que si”, que pode resultar interesante tamén para os adolescentes no relativo á estética e temáticas que vai abordando, como as relacións familiares ou os personaxes atormentados.

Os nove capítulos-estancias nos que se divide o miolo do libro son relacionados nun índice intitulado mapa de situación. Exploran a vida e obra do autor, así como distintos aspectos do seu estilo particular; ademais, os dous últimos apelan directamente aos admiradores do cineasta. Os oito primeiros manteñen a mesma composición gráfica na dobre páxina que os inicia: á esquerda a porta polo que se anima a entrar ao lector, e á dereita o letreiro que identifica a estancia (Figura 7); non obstante, o último dos capítulos-estancia, que corresponde coa área de descanso, varía lixeiramente (Figura 8).

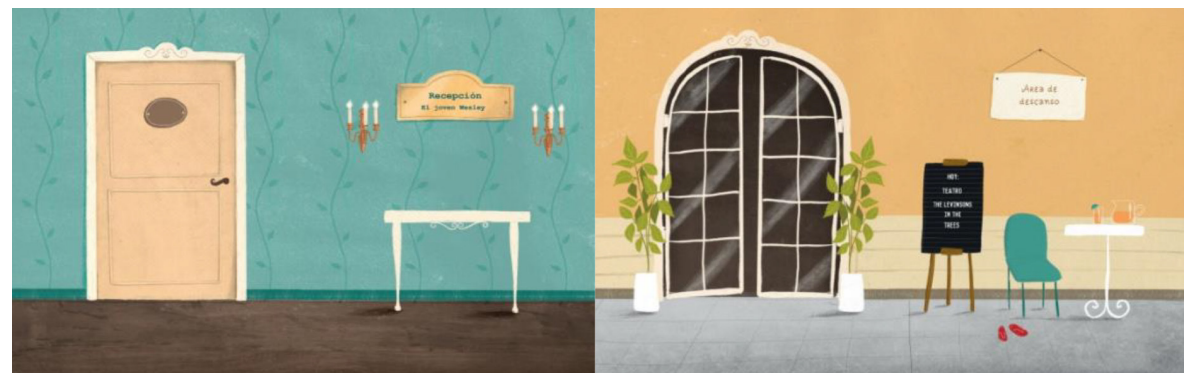

Figuras 7 e 8. (De esquerda a dereita) páxinas dobre de inicio do primeiro e último capítuloestancia.

Para entender mellor a maneira na que se estrutura o contido do libro, a táboa 1 recolle cada capítulo-estancia, a extensión, e os aspectos que se tratan:

\begin{tabular}{|c|l|l|}
\hline Páxinas & Título & Contido \\
\hline $11-35$ & $\begin{array}{l}\text { Recepción } \\
\text { El joven Wesley }\end{array}$ & $\begin{array}{l}\text { Biografía de Wes Anderson } \\
\text { Liña do tempo da súa produción fílmica }\end{array}$ \\
\hline $37-51$ & $\begin{array}{l}\text { Habitación 1 } \\
\text { Las influencias de un } \\
\text { bipster tejano }\end{array}$ & $\begin{array}{l}\text { Wes Anderson e o cine de autor } \\
\text { Principais influencias do cineasta }\end{array}$ \\
\hline $53-71$ & $\begin{array}{l}\text { Habitación } 2 \\
\text { Una oda a los raros }\end{array}$ & $\begin{array}{l}\text { Temas, estrutura e personaxes } \\
\text { O reparto nas películas de Anderson } \\
\text { (familia cinematográfica) }\end{array}$ \\
\hline
\end{tabular}




\begin{tabular}{|l|l|l|}
\hline 73-113 & $\begin{array}{l}\text { Habitación 3 } \\
\text { Las películas. Una } \\
\text { guía a su filmografía }\end{array}$ & $\begin{array}{l}\text { A orixe das películas do cineasta } \\
\text { Ficha filmográfica das súas películas: } \\
\text { título, ano, duración, artistas de guión, } \\
\text { sinopse, personaxes e curiosidades. } \\
\text { Anuncios e curtametraxes }\end{array}$ \\
\hline 115-149 & $\begin{array}{l}\text { Habitación 4 } \\
\text { «Buenos días. Soy el } \\
\text { señor Estilo» }\end{array}$ & $\begin{array}{l}\text { O estilo de Anderson: o poder da cor, } \\
\text { planos e movementos de cámara, vestiario } \\
\text { (uniformes e disfraces), obxectos cousas } \\
\text { curiosas, obxectos persoais, mobiliario, } \\
\text { obxectos de decoración, gafas gorros e } \\
\text { bigotes, medios de transporte), os libros } \\
\text { nas películas do cineasta, tipografía e outros } \\
\text { elementos gráficos }\end{array}$ \\
\hline $151-159$ & $\begin{array}{l}\text { Habitación 5 } \\
\text { Discoteca }\end{array}$ & $\begin{array}{l}\text { A música nas películas do cineasta } \\
\text { As bandas sonoras }\end{array}$ \\
\hline 161-173 & $\begin{array}{l}\text { Habitación 6 } \\
\text { Casas de muñecas }\end{array}$ & $\begin{array}{l}\text { Os espazos nos filmes de Anderson: } \\
\text { mundos en miniatura, espazos inventados e } \\
\text { localizacións }\end{array}$ \\
\hline $175-183$ & $\begin{array}{l}\text { Suite Júnior } \\
\text { El club de los } \\
\text { andersonianos }\end{array}$ & $\begin{array}{l}\text { O fenómeno fandom arredor da figura de } \\
\text { Anderson } \\
\text { Influencias posteriores: cine, moda, } \\
\text { decoración, gráfica e publicidade }\end{array}$ \\
\hline $185-201$ & Área de descanso & $\begin{array}{l}\text { Supertest arredor do cineasta } \\
\text { Postais das películas de Anderson } \\
\text { Diorama do Gran Hotel Wes Anderson }\end{array}$ \\
\hline
\end{tabular}

Táboa 1. Relación das páxinas, títulos e aspectos traballados nos capítulos-estancias.

Ademais da apelación directa ao lector mediante elementos textuais, o libro xoga coa experimentalidade derivada das posibilidades infinitas ofrecidas polo libro-obxecto no referido á significación da lectura como proceso interactivo, desenvolta por un lector activo e participativo, tanto a nivel físico como intelectual. Algúns exemplos destacables serían as receitas ou indicacións que o libro dá ao lector para poder ser Anderson, inserido na narración como personaxe representado (Figura 9), ou imitar a súa faceta como director (Figura 10); o xogo de identificación de obxectos nas películas do cineasta (Figura 11); o supertest proposto para a identificación do nivel de pertenza ao colectivo andersoniano do lector (Figura 12); ou o propio diorama final (Figura 13). 


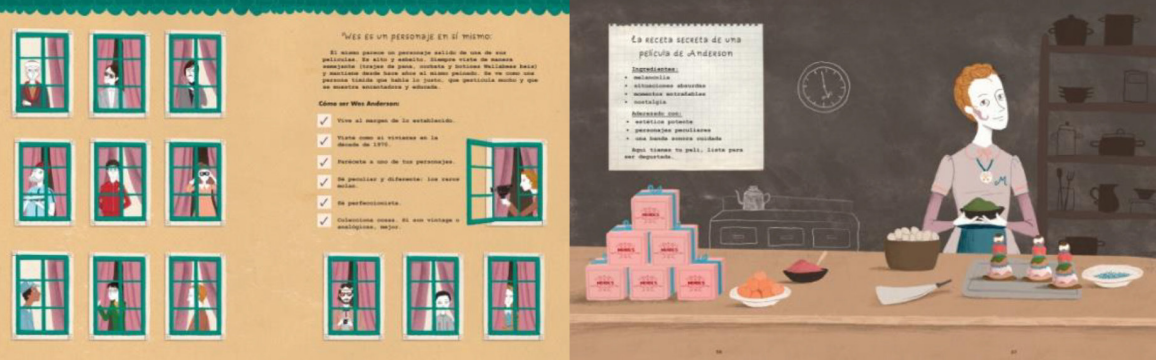

Figuras 9 e 10. (De esquerda a dereita) instrucións para ser Anderson e receita para facer unha película.

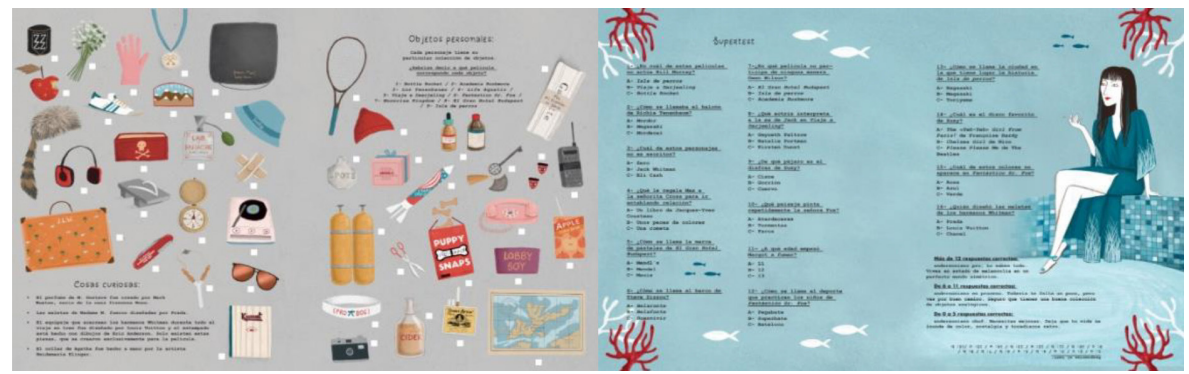

Figuras 11 e 12. (De esquerda a dereita) xogo de identificación de obxectos e Supertest.

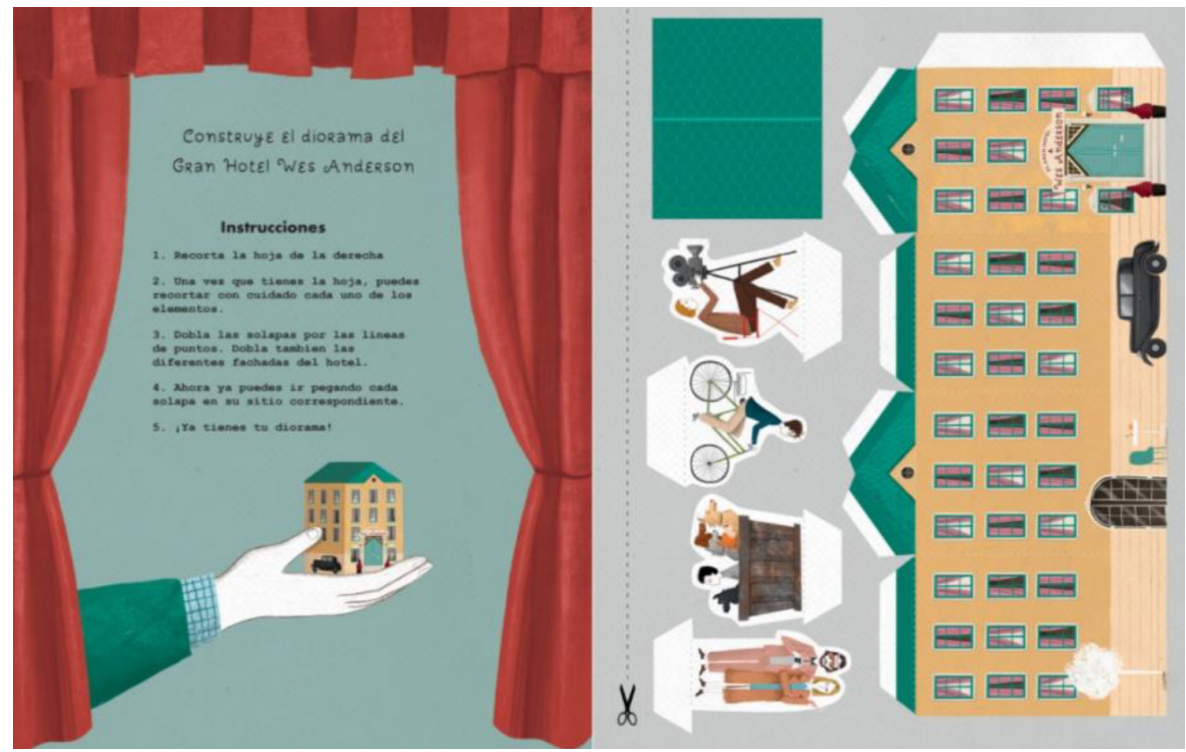

Figura 13. Dobre páxina do diorama. 
No relativo á construción visual da obra cómpre destacar o coidado estético e a importancia da ilustración na composición do libro e na maneira de representar cada elemento informativo, por exemplo, as fichas filmográficas das películas do cineasta (Figura 14) ou as paletas de cores (Figura 15).
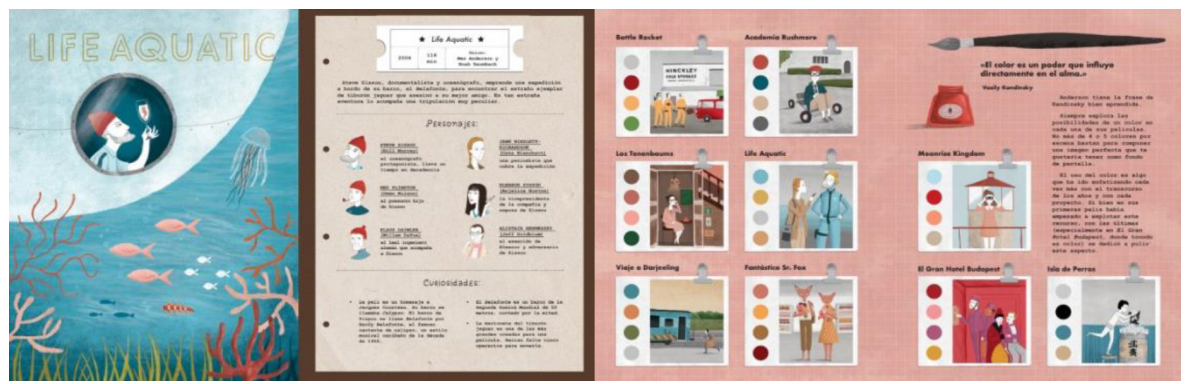

Figuras 14 e 15. (De esquerda a dereita) ficha filmográfica de Life Aquatic e paleta de cores.

Por último, o agasallo literario que a obra de Díaz fai ao cinema mediante un tratamento coidado, agarimoso e enaltecedor da figura de Anderson acentúase dedicándolle unha parte do quinto capítulo-estancia á importancia dos libros no labor profesional do cineasta dende catro modos de tratamento diferenciados: os libros que len os personaxes, os libros que escriben os personaxes, a estrutura das películas en capítulos e os libros nos que se inspiran algunhas das súas obras. Ademais, este punto de interese foi tamén tratado nunha das cuestións da entrevista realizada á ilustradora, ao preguntarlle a Díaz a súa opinión sobre os movementos de ida e volta entre a literatura e o cinema. A autora responde que se trata dun xogo proveitoso no cal todos os creadores se ven influenciados e que o interesante é recoller estas influencias e facelas propias e persoais, como fai Anderson. Nesta liña, Díaz conta que caeu nas redes do cineasta e saía do cine tras ver as súas películas cunhas ganas inmensas de debuxar, por iso se recoñece influenciada polas temáticas e, especialmente, no nivel conceptual.

\section{Discusión}

Unha vez presentados e comentados distintos aspectos da obra, neste apartado final interésanos reflexionar acerca do público obxectivo ao que vai dirixida e o público real que se somerxe na súa lectura e se identifica coa noción do lectorado empírico. En efecto, aínda que a nosa discusión asenta 
sobre evidencias, o seu propósito é máis espertar o interese polo rico campo de estudo dos libros-obxecto, cuxos diferentes niveis de lectura lle confiren unha posición ambivalente ${ }^{4}$.

Comezamos esta discusión final destacando a proposta do libro como unha invitación a entrar e percorrer as distintas etapas persoais e profesionais do director, de xeito que a lectura se converte, máis que nunca, nunha viaxe exploratoria. A obra pode ser entendida como un xogo de descubrimento a partir da lectura verbal e visual guiada polos compoñentes peritextuais, con elementos imbricados que retan o lector ou apelan á súa participación cocreativa.

Alén disto, consideramos que o contido da obra está principalmente pensado para o lectorado adulto ou, canda menos, xuvenil, xa que xira en torno a un cineasta cuxas películas non se dirixen de xeito explícito á infancia e cun nivel de especialización que parece precisar dun lectorado coñecedor ou interesado polo mundo do cinema a nivel técnico, estético, histórico, cultural etc. Non obstante, a riqueza e densidade de contidos informativos recollidos que apoia a nosa afirmación contrasta especialmente co estilo das ilustracións, que se relaciona facilmente co ámbito da ilustración de libros infantís e xuvenís, no cal a autora traballa habitualmente ${ }^{5}$.

Por outra parte, esta posible contradición na maneira de construírse unha proposta que atope con facilidade o seu lugar nun sistema de acollida, tamén se reforza pola introdución de xogos de preguntas, de identificación de obxectos e incluso a construción dun diorama. Pero de novo as fronteiras ou intencións non están claras, xa que no relativo ás dúas primeiras actividades propostas os coñecementos que se precisan para completalas con éxito non están ao alcance dos máis novos, polo menos de maneira sinxela. Ademais, a simulación do espazo figurado do hotel, en relación directa cunha das máis famosas propostas fílmicas do cineasta, volve mostrarse cómplice cos gustos dos máis novos e cunha tendencia habitual na creación de libros-obxecto para

4 A ambivalencia dos textos capaces de frecuentar dous sistemas literarios distintos comentada por Zohar Shavit (1986) está en relación directa co actual fenómeno das ficcións crossover que, con respecto á literatura infantil, fai referencia ás obras destinadas de maneira simultánea a xoves e adultos (Ramos e Navas, 2015).

5 Os seus traballos poden seguirse a través da páxina web da autora: https://www.nuriadiaz.es/ portfolio/. 
o público infantil, pero precisa dun lector cunha enciclopedia fílmica afastada da habitual nestas idades precoces para a decodificación completa da composición visual proposta.

En síntese, sería El Gran Hotel Wes Anderson unha obra pensada máis para un público adulto, infantil ou xuvenil? Son tantas as variables que a formulación dunha resposta única faise imposible. Ademais, habería que reflexionar acerca dos preconceptos que nos levan a relacionar un tipo de ilustración como o de Díaz, ou os libros que exploran a súa condición de artefactos a través da experimentación coa súa materialidade, co público infantil, de igual xeito que se fai, no mundo do cinema, coa animación. Non obstante, non perdemos de vista que se trata das tendencias predominantes na produción destas obras.

O que non se pode negar é que se trata dunha obra fermosa, coidada, planificada con detemento e, ante todo, ilustrada, xa que ao longo das súas 200 páxinas non hai un só lugar onde mirar e non deleitarse co estilo da súa autora. En efecto, o subtítulo da cuberta presenta o libro como "El universo ilustrado del cineasta más fascinante del mundo" e, alén da diversidade de opinións acerca da consideración feita sobre Anderson, non se podería definir mellor o seu contido.

\section{Referencias bibliográficas}

Carter, B. (2001) Libros de información: del placer de saber al placer de leer. Banco del Libro de Caracas.

Díaz, N. (2019). El Gran Hotel Wes Anderson. Lunwerg.

Equipo GLIFO (s.d.). Dicionario de Termos Literarios (DiTerLi). Santiago de Compostela: Xunta de Galicia e Centro Ramón Piñeiro para a Investigación en Humanidades. http://bernal.cirp.gal/ords/f? $\mathrm{p}=106: 50: \ldots:::$ :

Garralón, A. (2013). Leer y Saber, los libros informativos para niños. Tarambana.

Lugo Rodríguez, N. (13-14 de maio de 2010). Fanart y fanfiction, una estrategia de aprendizaje para los nativos digitales y sus profesores [Comunicación]. Congreso Euro-Iberoamericano de Alfabetización Mediática y Culturas Digitales, Sevilla. https://idus.us.es/xmlui/handle/11441/56148 
Mangarelli, M. (2020). Biografías para niños: Estrategias narrativas y pictóricas. Cuadernos de Literatura Infantil y Juvenil, 296, 34-45.

Mociño González, I. (2019). Libro-Obxecto e Xénero: Estudos ao redor do libro infantil como artefacto. Servizo de Publicacións da Universidade de Vigo. http://www.investigo.biblioteca.uvigo.es/xmlui/handle/11093/1631

Ramos, A. M. (2017). Aproximações ao livro-objeto: das potencialidades criativas às propostas de leitura. Tropelias \& Companhia.

Ramos, A-M. y Navas, D. (2015). Narrativas juvenis: o fenómeno crossover nas literaturas portuguesa e brasileira. Elos. Revista de Literatura Infantil e Xuvenil, 2, 233-256. http://dx.doi.org/10.15304/elos.2.2745

Rosenblatt, L. (2002) La literatura como exploración. Fondo de Cultura Económica de México.

Sampériz, M., Tabernero, R., Colón, M. J., e Manrique, N. (2021). El libro de no ficción para prelectores. Análisis de las claves de construcción del discurso. Cuadernos Del Centro De Estudios De Diseño Y Comunicación, 124, 73-90. https://doi. org/10.18682/cdc.vi124.4418

42 Shavit, Z. (1986). Poetics of Children's Literature. The University of Georgia Press.

Silva, S. R. da (2020). Clássicos da Literatura infantojuvenil em forma(to) de livro-objeto. UMinho Editora.

Silva, S. R. da (2020). Livros que são casas ou quando ler também é brincar. En C. Sousa Pereira (Org.), Literatura infantojuvenil: Livro-Objeto e patrimóni(os) (pp. 181-195). Tropelias\&Companhia.

Sousa Pereira, C. (2020). Literatura infantojuvenil: Livro-Objeto e patrimóni(os). Tropelias \& Companhia.

Tabernero Sala, R. (2017). O leitor no espaço do livro infantil. Para uma poé tica da leitura a partir da materialidade. En A. M. Ramos (Org.), Aproximações ao livro-objeto: Das potencialidades creativas às propostas de leitura (pp. 181-199). Tropelias\&Companhia.

Tabernero Sala, R. (2019). El objeto libro en el universo infantil: la materialidad en la construcción del discurso. Prensas de la Universidad de Zaragoza. 